This is an Accepted Manuscript of an article published by Tavlor \& Erancis Group in China Journal of Social Work on 13 May 2020 , available online: http://www.tandfonline.com/10.1080/17525098.2020.1756209.

\title{
Personal reflections on 30 years of social work development in China
}

\author{
Lena Dominelli
}

Faculty of Social Sciences, University of Stirling, Stirling, the United Kingdoms

\section{Contact: lena.dominelli@stir.ac.uk}

\section{Introduction}

It is a pleasure to celebrate 30 years of progress in social work development in the People's Republic of China (China). I do so through personal reflections on my journey into Chinese social work. My interest in China precedes my social work days. It stems from when I was a sociology undergraduate and came across Chairman Mao's Little Red Book which by then had captured the imagination of Western youth. I was enthralled by the idea of "Let(ting) 1,000 Flowers Bloom". I dreamt of going to China see this vibrant, thriving entity for myself. My vision has always been one of China drawing East and West together in new collaborative ways.

My dream of going to China was realised in the early 1980s after US President Richard Nixon and China's Deng Xiaoping, agreed to an open-door policy that enabled tourists to visit. I was among the first to do this. My entry to Mainland China was via Hong Kong, walking a few hundred yards from the train to the Chinese immigration control point where we were treated like VIPs, and given endless cups of tea. However, I was more interested in the sights that made me marvel at the amazing use of human labour and material resources. It stood in contrast to the waste I saw in the West. I could not believe how two older Chinese women carried between them a refrigerator on a bamboo pole as they ran between trains. Men were forming a human chain to unload a lorry full of cement bags. As a tourist, my visits were preplanned, and I was restricted to using money created especially for tourists (the yuan, that I called "funny money" because it looked more like vouchers of specific denominations than real notes, and were nothing like the renminbi used by Chinese shoppers). This money could only be used in stores developed especially for tourists and was a way for the state to obtain foreign currency.

But more intriguing to me were the obvious attempts concerning equality, an official policy at the time. The population was dressed in blue denim clothes called "Mao suits". Women were doing the same work as men. Everyone rode bicycles. This green form of transport impressed me as it formed an endless chaotic wave on the road, and I could not get across easily. Motor vehicles were limited to government officials, and trucks transported commercial goods. I went to various cities, including Beijing, Tianjin, Guangzhou and Shenzhen, and rural areas. The cities then had lovely traditional city centres, except for Shenzhen which was new, spotlessly clean and had been planned with wide boulevards and trees that would put any Western city to shame.

I thoroughly enjoyed the authorised visits to some exemplary communes, although I encountered various challenges - mosquitoes and my loathing for mosquito nets as I preferred screens on windows and doors to keep them out; human body wastes for fertilisers; soya sauce served in coffee pots; roast piglets served at banquets for honoured guests (I was vegan at the time); and factories that had little regard for the health and safety issues that had been addressed in the West. But I loved meeting the people, seeing their accomplishments, appreciating their hard work and resilience despite the hardships they endured, enjoying their sense of humour and friendship (through interpreters of course) and their faith in the future. And, the dedication of school children to their studies and thirst for knowledge was inspirational. It was very uplifting. I was privileged to ride ordinary trains, hire a car and an English-Chinese-speaking guide, visit restaurants, people's homes, schools and diverse workplaces. In these, I learnt about 
inclusive social policies like the "Iron Rice Bowl", universally accessible local healthcare systems, community support systems organised primarily by women and local CPC members, and ordinary people's belief in China's history, culture and achievements - past, present and future.

In the 1980s, I was particularly keen to experience the full implementation of socialist ideas. I was impressed to see women enjoying maternity care and abortion rights long before these became commonplace in the West. However, as a sociologist, alongside the amazing strengths and resilience evident among the rural population, I also saw the privileges enjoyed by members of the Chinese Communist Party - access to cars, better homes and holidays away from home. And, although workers were paid in work-points, I realised that women were being paid less than men for doing the same work and that domestic violence was as prevalent here as in the West. This saddened me for I realised that my search for the ideal way to organise human relations could not end there. Nonetheless, the tremendous strides that China has made in alleviating poverty, industrial transformation, modernising and becoming a superpower have to be applauded. China possesses enormous potential to lead the world in new directions guided by the socialist ideals of internationalism, equality, sharing resources and caring for others. Meanwhile, it is fantastic to see the enormous strides China has made in a few short years as it assumes its place among the leading nations of the world and works to promote peace and harmony within it.

\section{Formal social work in China}

My view is that China has a long tradition of and history in social work which has varied over time. The women's committees that I saw offering women support around health, fertility and family planning in the 1980s were doing social work, albeit informal and unqualified social work. Formal social work had already returned to the public arena by 1990 when I first encountered it through the good offices of Angie Yuen and Cecilia Chan in Hong Kong. They then hosted a meeting of the Board of the International Association of Schools of Social Work (IASSW), and I was then a Member-at-Large of IASSW. This introduced me to their endeavours in supporting the development of social work on the Mainland. I was delighted to have the opportunity to engage in this work and return to Mainland China. IASSW continued to support developments in that country, as it had before, particularly under the leadership of then-President Ralph Garber.

Several universities in Hong Kong were involved in the development of social work in Mainland China. Nonetheless, Angie Yuen and Cecilia Chan are two scholars who have been extremely influential in this. Additionally, a number of well-resourced American universities were involved. Their influence was strengthened later with further funding and the involvement of the American Council for Social Work Education (CSWE) which exposed China to American models of theory and practice, often highly focused on casework and clinical orientations.

However, the Hong Kong effect was qualitatively different. It emphasised social justice, equality and community development alongside working with individuals in diverse ways. IASSW was influential in the development of social work in what was then a British colony (on a long lease from China that ended in 1997) through the endeavours of Dame Eileen Younghusband who wrote several significant reports crucial to the development of social work in Hong Kong. Eileen Younghusband herself was also a President of IASSW from 1961 to 1968. Her model for social work remains important in Hong Kong, which now provides some of the best social work education and training in the world. Hong Kong's knowledge, skills and professionalism were pivotal in addressing the profession's needs in the People's Republic of China. Thus, the model of practice-based upon egalitarian partnerships that would bring local people and external collaborators together was born. 
I continued IASSW's tradition of supporting social work's development in Mainland China when I was elected President of IASSW in 1996 at the World Congress of IASSW in Hong Kong. It was here that I met the famous Professor Wang Sibin who was leading the development of professional social work in China from Peking University in Beijing. He was then President of the China Association for Social Work Education, and he presented me with a lovely lacquered plate from the Association, which I was delighted to accept. Unfortunately, I did not speak Chinese and Professor Wang did not speak English, so we smiled at each other and conversed through a translator. I understood the enormity of the task he was undertaking and was delighted to assist in whatever way I could, and in accordance with my principles of locality specific, culturally relevant social work, equality and inclusivity. China has much to offer the world as well as learn from it, and I termed it "reciprocated learning" through which research, curriculum development and practice teaching insights were shared and discussed among equals, with each one learning from the other in an exciting dialogical sharing of ideas and skills.

Sadly, what I could offer was limited to being a volunteer in a voluntary organisation with limited funding. However, email and the internet were becoming more used in academia, and it was becoming easier to ask IASSW members to help, and there were many from different countries including Ethiopia, South Africa, Colombia, Costa Rica, the USA, Canada, Sweden and Australia willing to do so under IASSW's auspices. I was re-elected the President of IASSW in 2000 for another four-year term. Under my Presidency, IASSW and IFSW (the International Federation of Social Workers) agreed the international definition of social work, the Global Standards for Social Work, and the ethical document for social work, all of which has inputs from Chinese colleagues. Their interventions highlighted the importance of Asian values, including the Chinese one of harmony which some felt were missing from these. The consultations around these documents and those involving the Global Agenda later provided examples of where China engaged with and contributed to world knowledge. At the same time, China has become a major economic, military and technological power as it assumes its place in leading the world more widely. Today, China has the potential of doing much good for humanity, and I hope that it will rise to the many challenges and opportunities that this presents.

When Abye Tasse from Ethiopia became President of IASSW in 2004, he brought even more scholars from the African continent to engage with our Chinese colleagues and promoted the development of the Global Agenda and regional observatories in which China participated through its representatives on the Board. Abye was succeeded as President by Angie Yuen from Hong Kong, and her extensive engagement in social work development in Mainland China became well-known to the IASSW Board. Angie invited many international scholars, including myself, to contribute to "training the trainers" seminars and conferences in Mainland China. And, she initiated the Social Dialogue magazine to disseminate information about cutting edge social work theory and practice globally. Internally in China, she was one of the guiding lights in social work development in Mainland China and ensured that Chinese social work educators were exposed to leading social work scholars across the world, and provided opportunities for her colleagues, e.g. Hok Bun Ku and Tim Sim to go to conferences overseas to present materials about new social work initiatives in Mainland China. Both scholars came to Durham several times to spend periods of time pursuing their research interests there. Vimla Nardkarnie from India became President of IASSW after Angie in 2012. She was followed by the current incumbent, Annamaria Campanini from Italy in 2016. Annamaria has had extensive involvement with China through the China-Europe Forum as well as IASSW, thus maintaining the strong collaborative links that this organisation has with Chinese scholars.

Those of us in IASSW mourn the recent passing of Professor Xu Yongxiang, an active member of the IASSW Board from 2008 to 2019, and President of the China Association for Social Work Education from 2016. Prof Xu came to Durham on a number of occasions and his 
warmth and generosity became well-known in its social work circles (I was located at Durham University before going to the University of Stirling). Scholars such as Prof Xu and Prof Yuen, among others, demonstrate the significant contributions that Chinese scholars have made to the international work. Prof Xu also hosted several meetings of the IASSW Board in Shanghai. Moreover, international relationship is not one way. For example, as President of IASSW, Angie Yuen has spearheaded China's contribution to the development in other Asian countries including Vietnam, Cambodia and Laos and remains involved in them. She also ensured that Chinese social workers engaged with important parts of the United Nations, particularly the UNISDR (United Nations International Strategy for Disaster Reduction, now Office for Disaster Reduction) to enable Chinese scholars to both contribute to and learn from others through various initiatives about disaster social work. She also established the PolyU-Peking University collaboration, which is based in the social work centre at the heart of the Peking University Campus.

\section{A Step-change in the development of social work in China}

The 2008 Wenchuan Earthquake which killed nearly 90,000 people was a wake-up call for social work in China. This event coincided with my research and practice in disasters which had begun with the 2004 Indian Ocean Tsunami], and formation of the Rebuilding People's Lives Network - (RIPL) post-disasters in IASSW in 2005. I was appointed its Chair, and this later morphed into my becoming the Chair of the Disaster Intervention, Climate Change and Sustainability in 2010. At the request of Angie Yuen, this expertise became available to Mainland China to enable social workers in enhancing their theory and practice in mitigating and responding to disasters. Under her leadership, Hong Kong Polytechnic University (PolyU) along with other universities from Hong Kong and elsewhere, went to assist the victimsurvivors of this catastrophic earthquake. Some of her colleagues, whom I had the honour to work within training sessions and learn from in the field, especially Tim Sim in Yingxiu and Hok Bun Ku in Caiopo. Under their guidance, the social work stations that they supported had moved away from narrow interventions to community-based disaster risk reduction, and, for $\mathrm{Ku}$ to holistic, transdisciplinary green social work (Ku 2011; Dominelli and $\mathrm{Ku} 2017)$. The GSW model for practice had been originally developed by Dominelli (2012) through participatory action research she had undertaken into the 2004 Indian Ocean Tsunami and climate change in 2009.

These beginnings were enhanced following the Wenchuan Earthquake in work endorsed by Angie Yuen and undertaken by Tim Sim and Lena Dominelli under the auspices of Earthquakes without Frontiers (EwF), a project funded by the British Research Councils, NERC and ESRC from 2012-2017 (Tim Sim; Dominelli, Sim and Cui). Angie Yuen supported PolyU's involvement through Tim Sim, and his leadership became crucial in developing disaster social work education and practice in Mainland China. Tim is also involved in EWF's follow-up project, PagerO, led by Prof Su of the Institute of Geology in the Chinese Earthquake Administration. Alongside this, the indefatigable fund-raiser without pareil (equal), Angie Yuen, was crucial in establishing the Disaster Management Institute at Sichuan University in Chengdu. Additionally, the drive, energy and commitment of individuals like Angie Yuen, Tim Sim, Hok Bun Ku, Sibin Wang, Yongxiang Xu and many others were critical in creating social work stations in many areas, especially in Sichuan and Yunnan, and producing new models of social work practice that have been shared with the rest of the world. These include the: Sichuan model of mental health which is a community based, empowering form of supporting victimsurvivors of disasters (Sim and Dominelli 2017); green community development to promote community-based, intergenerational, empowering relationships to renew traditional agricultural production and architectural development (Ku and Dominelli 2018). Much remains 
to be done in disaster social work, including developing practice placements for students, supervision mechanisms for practitioners; community-based disaster risk reduction strategies; and further curriculum development. More recently, GSW has also been used to provide guidance for social workers intervening in the novel coronavirus (Covid-19) which became a world pandemic in 2020. Some of these stories have been collected on the IASSW website (www.iassw-aiets.org), and there are contributions from China on this site. This sharing of information, knowledge and expertise becomes another mechanism whereby China continues its contributions to the global development of the social work profession.

Social work in China, as elsewhere, is having to respond to new, and seemingly intractable socio-economic issues and geophysical problems. These include:

- More "natural" and (hu)man-made disasters.

- Health pandemics, e.g., the novel coronavirus, Covid-19 which has challenged all countries.

- Migration including that caused by climate change.

- Organised crime that crosses borders.

- Military conflict versus peaceful resolution of disagreements between countries.

- High population growth and (mega)urbanisation.

- Sharing resources, including water and renewable energies.

- Controlling polluting industries and their impact on soil, water, air, other forms of environmental degradation, people's health and planetary well-being.

- Extreme weather events including droughts, heatwaves, floods and cold snaps.

- Sharing scientific knowledge, skills and expertise in transdisciplanry teams that include social work.

- Transdisciplinary and multiagency working in equitable, reciprocated partnerships.

- Service user and community engagement.

Disasters are complex situations that require holistic, transdisciplinary, interventions that sensitively involve and empower those affected. They require a clear understanding of the interactions between the social, political, economic, cultural and governance systems that contextualise disasters, the physical environment and diverse professions and organisations working alongside victim-survivors. Additionally, practitioners must comprehend the importance of meeting one's own professional development needs, having good ongoing (peer group and managerial) supervision as necessary, and self-care.

\section{Conclusions}

Social work in China has accomplished much in the past 30 years. It also faces many challenges. I identify these as follows:

\section{The achievements}

China can lay claim to the following:

- making huge strides in developing a large trained workforce, having established an aim of training 3 million in 10 years.

- developing new models for addressing modern social problems.

- envisaging and offering global leadership and playing a key role in developing community-based disaster reduction at the global level through its participation at the UN, in the Sendai Framework and at the UNFCCC (climate change), and IASSW.

- developing collaborative reciprocal relationships with other scholars. 
- spending more money on renewable energies than other countries, and thereby providing green social workers with a good basis for encouraging service users to develop resilient livelihoods using these technologies.

\section{The Challenges}

Social work in China faces many challenges, some it shares with other nations; some are unique to itself as a large, resourceful country attempting to meet the needs of a sizeable population for a decent quality of life. These include:

- maintaining quality among the trained workforce at levels attained by its best qualifying programmes in universities.

- resourcing a large academic, research and practice base in social work over time.

- developing more practice placements and supporting practitioners in the field to train in practice teaching as well as practice, and improve the quality of practice placements.

- devising a support and supervision system for practitioners working in disaster-prone areas.

- playing a critical role in facilitating peaceful, non-violent approaches to solving social problems locally, nationally and globally.

- preparing for and mitigating the impact of natural and (hu)man-made disasters, including climate change that is increasing in frequency and intensity globally.

- ensuring that most humanitarian aid workers, whether volunteers or not, become trained in the disaster and relief fields.

- supporting social workers, who as second-tier responders (after the military, police and firefighters evacuate disaster victim-survivors to safety) must support and care for others. Additionally, if these practitioners are victim-survivors themselves, they also require appropriate training and support.

- providing social workers who support the victim-survivors of disasters with adequate supervision and debriefing while they are handling critical incidents and catastrophes.

- providing social workers with training in how to intervene in disasters at the qualifying level, in specialist Masters' Programmes, and post-qualifying continuing professional development (CPD) level.

- ensuring that social workers act ethically at all times and that the principle of doing no harm is observed. Implementing this may require the formation of a professional regulatory mechanism or organisation.

- upholding the centrality of critical, reflective practice and good communication skills for all practitioners.

Despite the length and nature of challenges in this list, there is no doubt that China will do its utmost to rise to the challenges. And, in the course of doing so, it will offer leadership not only to its own nationals but to all social workers globally who share its vision of a less disaster-prone world.

\section{References}

Dominelli, L. 2012. Green Social Work: From Environmental Crises to Environmental Justice. Cambridge: Polity.

Dominelli, L., and H. B. Ku. 2017. "Green Social Work and its Implications for Social Development in China." China Journal of Social Work 10 (1): 3-22. doi: 10.1080/17525098.2017.1300338. 
Ku, H. B. 2011. “'Yingxiu Mother' as Agent of Development - a Case Study of Rural Social Work Intervention in Sichuan Post-disaster Community in China". Korean Journal of Rural Welfare Studies 7: 33-54.

Ku, H. B., and L. Dominelli. 2018. "Not Only Eating Together: Space and Green Social Work Intervention in Hazard Affected Area in Ya'an, Sichuan, China." British Journal of Social Work 48 (5): 1409-1431. doi: 10.1093/bjsw/bcx071.

Sim, T., and L. Dominelli. 2017. "When the Mountains Move: A Chinese Post-disaster Psychosocial Social Work Model." Qualitative Social Work 16 (5): 594-611. doi: $10.1177 / 1473325016637912$. 